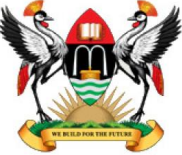

East African School of

Higher Education Studies \& Development
Makerere Journal of Higher Education

ISSN: 1816-6822; 5 (1) (2013) 91 ï 102

DOI: http://dx.doi.org/10.4314/majohe.v5i1.7

(C) The Author(s) 2013

Reprints \& permission: EASHESD

http://ajol.info/majohe

\title{
Distance Learning Centres and Administrators' Quality Assurance Implementation in Nigeria
}

\author{
C. N. Ozurumba ${ }^{1, *}$, Patrick Oladunjoye ${ }^{1}$ \\ ${ }^{1}$ Department of Educational Foundations, Niger Delta University, [*Corresponding author. E- \\ mail: ozujumba@gmail.com]
}

\begin{abstract}
Implementation of the concept of quality assurance is central to the performance of all educational institutions of learning and those operating outside the norm of traditional academic setting such as National Open Universities. Against this background, this study undertook to verify four hypotheses related to quality assurance in distance education in Nigeria. An ex-post facto research design was adopted for the study. A sample of 1,033 Academic staff were randomly selected from a population of two (2000) thousand staff. The selection was done through multistage sampling technique. A research instrument titled: Educational Administrator Quality Assurance Implementation Questionnaire. (EAQAIQ) was used for data collection. Pearson Product Moment Correlation was the statistical tool used for data analysis. The result of the study indicates that a significant relationship exists between quality assurance implementation and the systems performance. Based on the results, the study recommends that: Educational administrators should recruit qualified academic staff to teach and perform commensurate with their wealth of professional experience and qualification.
\end{abstract}

Keywords: Open and Distance Learning (ODL); Quality assurance; Nigeria.

\section{$1 \quad$ Introduction}

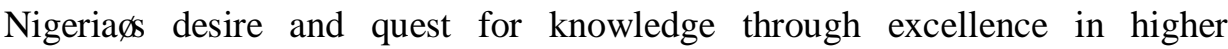
education in the past ten years has culminated in the development of Distance Education. Today, Distance Education is one of the fast growing fields of education and training in the country. According to UNESCO (2000), realization of the importance of distance education as an essential component of the economy has influenced governmentsôinterest in ensuring quality delivery through continuing education. Using this education institution as a pivot for its 
(quality assurance) will remain unrealizable if administrators of these institutions are not efficient and effective in quality assurance implementation.

On this note, Adepoju (2000) asserts that no organization, public or private, formal or non-formal, can successfully accomplish its goals without any consideration for efficiency and effectiveness of its internal and external operations. Those who implements quality assurance programmes should involve the administrators of educational institutions in their efforts in such a way as to obtain better results of the goals of the distance learning institutions (ODL). This effort has to do with taking measures to remove any fault at the end of the production of educated, employable, disciplined and cultured individuals in the society.

In support of this opinion, Patru (2002) emphasized that ODL institutions should be stimulated by administratorsôinterest in the use of new technology based information and recognition that quality assurance in education requires innovative methods of restructuring the system for improved performance. Unfortunately, most of the nationô higher education administrators seem to be lacking in their administrative abilities and expertise of supervising programme of instruction, lacking of professional competence, inability to prudently manage available fund and poor curriculum organization and implementation (Vrah, 1995). Furthermore, Denga (1998) stressed that many school managers have non-challant attitude towards appreciating and rewarding teachers and students who are the key factors in the teaching learning process. With these problems and challenges the quality and quality assurance implementation of the school programmer may not be achieved.

Generally, the researchers has observed that; in Nigeria today, education has been counter-productive because it has undergone rapid changes with attendant policy somersault and implementation problems that arise mainly from lack of sufficient political will to foster quality assurance towards improvement of individuals and society. Nwaoku, (2002) observed that many programmes offered by Distance Learning educational Institutions are known to have been either destroyed due to school administratorsô lack of vision and mission to plan, or made unworkable because of poor strategies for implementation. Therefore, as a matter of urgency, Government needs to embark on quality drive through teacher quality programme. Teachers, as resource inputs into the educational process, are the most important of all the inputs that would give assurance of quality implementation. This is pertinent because educational administratorsô quality assurance, implementation requires teachers of the higher quality for a successful quality assurance results.

The issue of quality assurance implementation cannot be discussed without giving consideration to human resource of any country as its greatest asset. When the right quality of human resources in the right quality, is appropriately 
deployed, would be able to convert the distance learning centres resources to useful products (Harvey, 1999).

In support of the above observation, Ramon-Yusuf (2002) affirmed that quality of human resources in the university system can only be attainable and implemented through effective instructional supervision and working with people who are working with students of the institution. According to Gooley and Lockwood (2006), the resources available for the development of knowledge are far from evenly distributed. This has contributed immensely to reducing administratorsô effort towards quality implementation in school. Inputs into the system are inadequate. The nature of infrastructure and instructional materials are in the state of insufficiency. Mkpa (2008) posited that good quality resources are positively related to quality assurance implementation process.

Scholars like Ikenga-Metuh (1997), Yusuf (1995) Soyinka and Gana (1995) opined that the best way to change the Nigerian distance learning education was to strengthen our democracy and meet the challenges of this millennium is to guarantee a universal qualitative and excellent implementation of the system. Administrators of the educational system according to Vrah (1995) have a foresight and dynamism which can be a relevant launching pad to our yarning for a successful quality assurance implementation of educational programmes in distance learning institutions, practically however, only a few aspects of the quality assurance implementation policy are being realized while some of them still remain a mirage. This unfortunate situation could be blamed on governmentôs consistent poor attitude towards the education sub-sector manifested in dishonest financial allocations to the sector and administrators ineffective financial management. In support of this opinion, Panda (2005) Peters (2005) and Umoru-Onuka (2001) affirmed that management (including planning) is central to and an essential part of distance learning. They concluded by asserting that obviously, management of distance learning educational institutions and their managers must be innovative and dynamic if quality assurance implementation of programmes is to be effective and successful.

For quality assurance implementation to be effectively implemented by educational administrators, a good quality management techniques or style must be built into any distance learning programme effectiveness and efficient service delivery for whereby teachersôare adequately rewarded and recognized. More so, government apathy towards teacherôs welfare has been a re-cycled problem affecting quality assurance implementation in our distance learning education system (Denga, 1998). 


\subsection{Statement of the Problem}

Recent developments in the Nigerian open and distance learning university system seems to indicate that all is not well as expected with quality assurance implementation policy and programmes of school administrators. Ajayi (2005) maintained that the scenario appears worrisome when viewed against the background that Nigeria once served as the hub and most successful in the leadership of quality assurance implementation programme of tertiary educational institutions. As a matter of fact, today, things are no longer the same in distance learning institutions, as quality assurance implementation of the programme seems to be under serious threat due to ineffective leadership, poor financial management and infrastructural decay, lack of accommodation for students and unstable academic calendar among others (Okon and Ayuk, 2005). This situation brings to bear on the extent to which quality implementation of programmes is assured in these centres of learning. It is against this background that this study looked into the issues of quality assurance in Distance Learning Centres of our Universities.

\subsection{Purpose of the Study}

The main purpose of this study was to ascertain the extent to which educational administrators implement quality assurance in the administration of distance learning educational institution towards enhanced academic performance. Specifically the study was designed:

1. To ascertain the extent to which distance learning university administratorsô instructional supervision relates with the performance of the system.

2. To ascertain the extent to which distance learning university administratorsô attitude to lecturersôprofessional advancement relates with the performance of the system.

3. To ascertain the extent to which distance learning university administratorsô maintenance of minimum academic standard relates with the performance of the system.

4. To ascertain the extent to which distance learning university administratorsô management of fund relates with the performance of the system.

\subsection{Hypotheses}

The following hypotheses were formulated to guide the study:

1. There is no significant relationship between distance learning university administratorsôinstructional supervision and performance of the system.

2. There is no significant relationship between distance learning university administratorsôstaff development policy and performance of the system. 
3. There is no significant relationship between distance learning university administratorsô financial management with regard to quality assurance implementation and performance of the system.

4. There is no significant relationship between distance learning university administratorsô maintenance of academic standard with regard to quality assurance implementation and performance of the system.

\section{$2 \quad$ Methodology}

This study adopted a descriptive ex-post facto design. The design was adopted because the variables under study had already occurred before the researchers conducted the research. The population of the study consisted of two thousand $(2,000)$ staff of open distance learning centres in Nigeria. Through multistage sampling technique, one thousand and thirty-three $(1,033)$ respondents were selected as sample for the study, which represent $51.6 \%$ of the population. The researchers appointed two assistant researchers in each centre who helped in collection of data from respondents. The process of data collection lasted for three months.

The instrument used for the study was Educational Administrator Quality Assurance Implementation Questionnaire (EAQAIQ) which was made up 60 items and structured to present the respondents with a fixed set of choices. A four-point Likert scale was used to rate the perception of the respondents. Strongly Agree (SA), Agree (A), Disagree (DA), Strongly Disagree (SD).

The validity of the instrument was established through submission of the copies of the instrument to two experts in measurement and evaluation to confirm their face and content validity. Ambiguous and irrelevant items were dropped and the instrument was reviewed and improved upon. The reliability of the instrument was determined through the split-half method using 50 lecturers in five centres. The subjects used in the trial testing did not constitute part of the main sample of the study although they had similar characteristics as the respondents. This was to avoid bias. The responses were then split into two for each respondent, such that all odd number responses were on one half while even number responses were on the other half. The aggregate scores of the respondents from the two halves formed pairs of scores for each of them. These pairs of scores were then correlated using Pearson Product Moment Correlation Coefficient (r). The result obtained was then subjected to spearman Brownôs prophecy formula to correct for the split. The indices of the variables ranged between 0.73 and 0.88 which was high enough to justify the use of the instrument for data collection. 


\section{Result}

The result focus on the statistical analysis of data gathered for this study. The presentation of the data was done following the trends of the four (4) hypotheses directing this study. In this section therefore, each hypotheses of the study is restated, the variables are identified and the techniques for data analysis is specified.

\section{Hypothesis 1}

There is no significant relationship between administratorsô instructional supervision and the system performance of distance learning institutions with regard to admission policy, learning environment, instructional services delivery, and academic record keeping.

The result of the analysis is presented in table one. The result of analysis in table one show that the calculated r-value for the relationship between educational institution administratorố instructional supervision and admission policy, (0.268), learning environment (0.433), instructional services delivery (0.396), academic record (0.385) and overall institution system performance (0.468) were each greater than the critical $r$-value of 0.062 at .05 level of significance with 1031 degrees of freedom. This means that there is a significant positive relationship between administrators Instructional Supervision and all sub-variables of an overall institutional performance. That is the better the educational administratorsôinstructional supervision, the better the institution system performance, hence, the null hypothesis is by this result rejected.

Table 1: Educational Administrator's Instructional Supervision and Open University system performance $(\mathrm{N}=1033)$

\begin{tabular}{lllll}
\hline Variables & $\begin{array}{l}\sum \mathbf{x} \\
\sum \mathbf{y}\end{array}$ & $\begin{array}{l}\sum \mathbf{x}^{2} \\
\sum \mathbf{y}^{2}\end{array}$ & $\sum \mathbf{x y}$ & $\mathbf{R}$ \\
\hline $\begin{array}{l}\text { Educational Administrators' Instructional } \\
\text { Supervision }\end{array}$ & 20137 & 409457 & & \\
Admission policy & 17044 & 290142 & 337736 & $0.268^{*}$ \\
Learning environment & 18966 & 358990 & 377488 & $0.433^{*}$ \\
Instructional service delivery & 19570 & 37626 & 388609 & $0.396^{*}$ \\
Academic record keeping & 19431 & 375145 & 385926 & $0.385^{*}$ \\
Overall institution system performance & 182273 & 32734263 & 3628354 & $0.468^{*}$ \\
\hline
\end{tabular}

${ }^{*} \mathrm{P}<.0 .5 ; \mathrm{df}=1031 ;$ critical $\mathrm{r}=0.062$ 


\section{Hypothesis 2}

There is no significant relationship between educational institution administratorsô attitude towards lecturersô professional advancement and system performance of distance learning centres with regard to admission policy, learning environment instructional services delivery and academic record keeping. The result of the analysis is presented in Table 2 .

Table 2: Relationship between Educational Administrators' Professional Advancement and System Performance $(\mathrm{N}=1033)$

\begin{tabular}{lllll}
\hline Variables & $\begin{array}{l}\sum \mathbf{x} \\
\sum \mathbf{y}\end{array}$ & $\begin{array}{l}\sum \mathbf{x}^{2} \\
\sum \mathbf{y}^{2}\end{array}$ & $\sum \mathbf{x y}$ & $\mathbf{R}$ \\
\hline Institutional administrators attitude & 17561 & 310777 & & \\
toward advancement & 17044 & 290142 & 293178 & $0.328^{*}$ \\
Admission policy & 18966 & 358990 & 328080 & $0.493^{*}$ \\
Learning environment & 19570 & 37626 & 337089 & $0.422^{*}$ \\
Instructional service delivery & 19431 & 375145 & 335729 & $0.497^{*}$ \\
Academic record keeping & 182273 & 32734263 & 3162170 & $0.550^{*}$ \\
Overall institution system performance & & & & \\
\hline
\end{tabular}

* $P<.0 .5 ; \mathrm{df}=1031 ;$ critical $r=0.062$

Result of analysis in Table 2 show that the calculated r-values for the relationship between administratorsô attitude towards lecturers professional advancement and admission policy (0.328), learning environment (0.493), instructional service delivery (0.422), academic record (0.497) and overall system performance $(0.550)$ were each greater than the critical r-value of 0.062 at .05 level of significance with 1031 degree of freedom. This means that, there is a significant positive relationship between educational institutional administratorsô attitude towards lecturersô professional advancement and all sub-variables of all overall system performance. That is, the more effort the attitude of educational administrators towards staff development the better the institutional system performance. The null hypothesis is, by this result rejected.

\section{Hypothesis 3}

There is no significant relationship between institutional administratorsô financial management and system performance of distance learning centres with regard to admission policy, learning environment, instructional service delivery and academic record.

The result of the analysis is preserved in table three which show that the calculated $r$-values for the relationship between administrators financial management and admission policy (0.286), learning environment (0.5 13) instructional service delivery (0.532), academic record (0.536) and overall 
schoolsô system performance (0.062) of .05 level of significance with 1031 degrees of freedom.

This means that there is a significant positive relationship between administratorsôfinancial management and system performance. That is, if the administrator manages institutional finance very prudently the will be improved performance of the system. The null hypothesis, going by the result is rejected.

Table 3: Relationship between administrators' Financial Management and System Performance

\begin{tabular}{|c|c|c|c|c|}
\hline Variables & $\begin{array}{l}\sum x \\
\sum y\end{array}$ & $\begin{array}{l}\sum \mathbf{x}^{2} \\
\sum \mathbf{y}^{2}\end{array}$ & $\sum x y$ & $\mathbf{R}$ \\
\hline $\begin{array}{l}\text { Institutional administrators financial } \\
\text { management effort }\end{array}$ & 16922 & 299534 & & \\
\hline Admission policy & 17044 & 290142 & 28324 & $0.286^{*}$ \\
\hline Learning environment & 18966 & 358990 & 319881 & $0.593^{*}$ \\
\hline Instructional service delivery & 19570 & 37626 & 328074 & $0,532^{*}$ \\
\hline Academic record keeping & 19431 & 375145 & 326168 & $0.536^{*}$ \\
\hline Overall institution system performance & 182273 & 32734263 & 3075487 & $0.616^{*}$ \\
\hline
\end{tabular}

${ }^{*} \mathrm{P}<.0 .5 ; \mathrm{df}=1031 ;$ critical $r=0.062$

From the analysis above, the composite effect and the relative effect of distance learning institutions administratorsô effort towards quality assurance implementation and the system performance were further explored, using the multiple regression analysis. The result of the analysis is presented in table 4 and 5 respectively.

Results of analysis on table four are on the combined effect of the predictor variables on the criterion variable. The results therefore show that the calculated f-ratio of 229.951 is greater than the critical f-ratio of 2.09 at .05 level of significance with 1.026 and 6 degrees of freedom.

Table 4: Multiple regression analysis showing the composite effect of institutional administrators' quality assurance implementation on the institutions performance

\begin{tabular}{llll}
\hline Source of ss Variation & Df & Ms & F \\
\hline Regression 55284.848 & 6 & 9124.141 & $229.951^{*}$ \\
Residential 41111.808 & 1026 & 40.070 & \\
Total & 96396.658 & 1032 & \\
\hline
\end{tabular}

$\mathrm{R}=0.757$

$\mathrm{R}^{2}=0.574$

Standard error $=6.33009$

${ }^{*} \mathrm{P}<.0 .5 ; \mathrm{df}=6 ; 1026$, critical $F=2.09$ 
Table 5: Multiple regression analysis showing the relative effect of Administrators quality assurance implementation on institutional performance

\begin{tabular}{llllll}
\hline Variables & B & $\begin{array}{l}\text { STD } \\
\text { ERROR }\end{array}$ & BETA & T & Sng \\
\hline Constant instructional supervision & 24.747 & 1.620 & & $1527.3^{*}$ & .000 \\
Attitude to Professional Advancement & 0.629 & 0.071 & 0.201 & 8.819 & \\
Lecturers & 0.758 & 0.089 & 0.259 & $8.530^{*}$ & .000 \\
Financial Management & 0.724 & 0.076 & 0.0274 & $9.533^{*}$ & .000 \\
\hline
\end{tabular}

$P<.05$

The statistical analysis implies that there is a significant combined (composite) effect of administratorsô instructional supervision, attitude to professional, financial management on institutional performance.

Further examination of the result show that the general regression coefficient (R) was 0.757 implying that the predictors regressed significantly with the criterion. The $\mathrm{R}^{2}$ value, which reflect the variances in the prediction accounted for by the variables used for the study was 0.574 . That is, the variables used for the study accounted for $57.4 \%$ of the variability in the study. Accordingly, therefore, the results imply that the other $42.6 \%$ of the variable is accounted for by extraneous variables originally not controlled in the study.

\section{Discussion, Conclusion and Recommendations}

The result of the first hypothesis indicated a significant positive relationship between university administratorsô instructional supervision and system performance of distance learning institutions. This means that distance learning institution perform better with an efficient administrators. The findings of this hypothesis is in agreement with Ogunsaju (1983) who pointed out that instructional supervision by an efficient school manager improves effective performance of educational institution so that these institutions can contribute maximally to the attainment of educational goals. He further submits that effective administrators focus on studentsô outcome through analysis of studentsôdata, evaluate the curriculum and instructional approaches.

In support of this observation, Ajayi (2005) opined that administrators of educational institutions should endeavour to regularly carry out instructional supervision of their institutions to ensure quality especially in the areas of staff lesson delivery. In the same light, Adiomere and Ekwevugbe (2005) in their findings research revealed that school administratorsôinstructional supervision leads to effective monitoring of the learning environment and implementation of quality education programmes. 
Contrary to this view, Okon and Ayuk (2005) posit that poor supervision of instruction in education institution has been responsible for poor school performance in academic studies. Their findings also show that inappropriate admission policy leads to high population of students in the distance learning of instructions and consequently poor performance of students and teacher. Confirming this assertion, Ocho (2005) observes that the fallen standard of education in the state could be attributable to the lack of job satisfaction among teachers.

The result of the second hypothesis indicated a significant positive relationship between Administrators attitude to staff professional advancement and system performance. This means that the more positive in attitude the school administrator is towards staff development, the better the performance of the school system. The findings of this study is in agreement with the work of Odigbo (2005) who carried out research in a distance learning and private education in Nigeria educational system with implications for quality assurance and system performance. He concluded that private schools have better qualified teachers than the traditional open distance learning institutions. This could be as a result of in-service training opportunity for their staff.

In support of this view, Adegun (2005) opined that staff development increase their productivity, enhance teachersô morale and assist them in adapting to the eve- changing technological world. Education institution managers whose attitude is to constantly provide for staff development, competence and good quality; often contributes to their job effectiveness towards quality assurance implementation of the school programme for improved performance.

Furthermore, the result of hypothesis three indicated a significant positive relationship between school administratorsôfinancial and systemô performance of open distance learning institution. This means that the better the financial management pattern of education institution leaders, the better the performance of the system. The findings of this hypothesis is in line with the result of a study by Unachkwu (2007) who opined that financial and property management as an aspect of educational accountability and progress, leads to quality assurance implementation of education programmes.

In another dimension, Ogbodo and Nwaoku (2007) asserted that without the management abilities of the open distance learning administrator, the administration of the school would crumble, quality implementation of programmes and the systems performance would remain unachievable. Nwaoku (2002) affirmed that an educational institution administrator can be effective in his management of funds, when he is not being wasteful but prudent in financial matters. This would lead to maintenance of transparent financial records, motivate staff, enhanced teaching and learning towards quality assurance implementation and improved academic performance. 
From the analysis of the study, the researcher concluded that there is existence of positive relationship between open university administratorô instructional supervision effort and the performance of the school system. This indicates those university administrators who go round or make regular checks on staff that are performing their duties, are more likely to achieve a better performance of the system. His attitude to staff development or professional advancement enhances system performance. In other words, when the school administrators encourage issues relating to staff welfare, productivity could be enhanced despite the nature of the learning environment. To ensure implementation of quality in the education system there is need for adequate fund to be provided. This would no doubt contribute immensely to improvement of the systems performance.

Therefore, the university administrators should hold regular conferences, seminars and workshops with staff and address them on improvement of instructional supervision towards enhancement of the performance of the system. The open universitiesôdistant learning authorities in conjunction with the Ministry of Education and state secondary education board should organize a well-planned growth oriented professional training/ in-service courses for sustenance of quality education. The university administrator should maintain transparent financial management ability by being prudent in financial matters. Finally, it is recommended that educational administrators recruit adequately qualified academic staff to teach and perform commensurate with their wealth of professional experience and qualification for improved performance.

\section{References}

Adegun, O. A. (2005). Comparative Study of the Administrative Effectiveness of Head Teachers in Public and Private Primary Schools in Ekiti State. Nigeria Journal of Educational Planning, 2 (5), 196-200.

Adepoju, T. L. (2000). Improving Educational Efficiency in Nigeria. A Planner's View. Ibadan: National Institute for Educational Planning and Administration.

Ajayi, A. E. (2001). Human Resources Management in the Civil Service. A paper Presented at the Senior Staff Seminar, Ministry of Education AdoEkiti, March 1.

Denga, D. I. (1982). Managerial Psychology in Work Organizations. Jos: Savannah Press.

Gooley, V. M. and Lockwood, N. A. (2006). The impact of quality monitoring on institutions: Quality In Higher Education, 3 (1), 8 7-94. 
Harvey, L. (1999). Transforming Higher Education Buckingham: SRHE and Open University Press.

Ikenga-Metuh, H. (1997). Good Citizenship through University Education. Onitsha: Midfield Publishers.

Nwaoku, I. C. (2007). Quality Control Measures in the Management of Tertiary Institutions. Issues and Concerns, Ondo: Owalegbo press.

Odigbo, C. I. (2005). Public and private secondary schools dichotomy in the Nigerian education system: implication for quality education. Nigerian Journal of Educational Administration and Planning, 2 (5), 164-1 72.

Ogunsaju, S. (1983). Educational Supervision: Perspective and Practices in Nigeria. Ile-ife: University of Ife press.

Panda, L. (2005). Quality Management ITS Imperatives and key Concepts. Dura press.

Patru, M. (2002) Open and Distance Learning Trends Policy and Strategy Considerations. UNESCO 2002.

Peters, O. (2005). Distance teaching and Industrial production. A Comparative interpretation in Outline. Distance Education International Perspective, London. Honour of professor (Mrs.) Ebele, J. Maduewesi. Benin City: Daslyva, 12-25.

Ramon-Yusuf, S. (2002). The role of the National Universities Commission in Quality Assurance in Nigerian Universities. A paper presented at the department of Academic Planning and Research Seminar. 25 February, 2002.

Soyinka, O. S. and Gana, T. (1995). Quality Assurance Implementation Process. Santiago: Chile May 1995.

Umoru-Onuka, A. O. (2001). Implementation of Mastery Learning Strategy in Nigeria: the instrument implementation. A paper presented at the WAEC, monthly seminar (February).

Unachkwu, G. O. (2007). Educational Accountability of Network and School effectiveness. Nigerian Journal of Educational Administration and Planning, 7 (2), 19-32.

UNESCO (2000). The State of Education in Nigeria, Abuja: Nigeria. 
